\title{
Effect of salinity acclimatisation and administration of hormones on oocyte maturation, ovulation and spawning of goldspot mullet Liza parsia (Hamilton, 1822) reared in brackishwater pond
}

\author{
PREM KUMAR, G. BISWAS, T. K. GHOSHAL, L. CHRISTINA, P. BEHERA AND M. KAILASAM* \\ Kakdwip Research Centre of ICAR - Central Institute of Brackishwater Aquaculture (CIBA), South 24 Parganas \\ West Bengal - 743 347, India \\ *ICAR - Central Institute of Brackishwater Aquaculture, 75-Santhome High Road, R. A. Puram, Chennai - 600028 \\ Tamil Nadu, India \\ e-mail:prem.cife@gmail.com
}

\begin{abstract}
Two separate experiments were conducted to evaluate the effect of salinity acclimatisation and administration of hormones on oocyte growth of Liza parsia (Hamilton, 1822). In the first experiment, broodstock fishes in the sex ratio of 2:1 (male:female) were acclimatised to $30 \mathrm{ppt}$ salinity (which is the desired salinity for breeding L. parsia) in 24, 48 and $72 \mathrm{~h}$ of duration ( $\mathrm{n}=6$ ). Oocyte diameter from the experimental fishes were measured before and after salinity acclimatisation. The results showed that the acclimatisation to breeding salinity reduced oocyte diameter $(p<0.05)$ in female fish and increased sperm relative mortality $(\mathrm{p}<0.05)$ in male fish. In the second experiment, males and females in the similar sex ratio $(2: 1)$ were acclimatised to the desired salinity of $30 \mathrm{ppt}$ in $24 \mathrm{~h}$. Subsequently, carp pituitary gland extract (PGE), human chorionic gonadotropin (HCG), combination of PGE+HCG and luteinising hormone releasing hormone analogue (LHRHa) with dopamine antagonist (DA) metoclopramide were injected intramuscularly, The dosages used were: PGE- 0.01 and $0.02 \mathrm{mg} \mathrm{g}^{-1}$; HCG - 20 and $40 \mathrm{IU} \mathrm{g}^{-1}$, LHRHa - 10 and $20 \mu \mathrm{g} \mathrm{kg}^{-1}$ as primary and secondary doses, respectively. Metoclopramide was injected at the dose of $15 \mathrm{mg} \mathrm{kg}^{-1}$ along with LHRHa. Results of the second experiment indicated that the administration of PGE or PGE+HCG is essential for final oocyte maturation and ovulation in salinity acclimatised L. parsia.
\end{abstract}

Keywords: Dopamine antagonist, Gonadotropin, Liza parsia, Luteinizing hormone, Oocytes growth, Salinity

\section{Introduction}

Goldspot mullet Liza Parsia (Hamilton, 1822) is a euryhaline fish that thrives well in freshwater, brackishwater and seawater (Riede, 2004). It is a migratory species that spawns in seawater (Talwar and Jhingran, 2001). Similar to other fish of commercial importance to the aquaculture sector, L. parsia also exhibits reproductive dysfunctions in captivity. These dysfunctions in fish are probably due to the cumulative effect of captivity induced stress (Sumpter et al., 1994; Pankhurst and Van der Kraak, 1997), lack of appropriate natural spawning environment (Zohar, 1989; Yaron, 1995; Battaglene and Selosse, 1996) and inhibitory role of dopamine on release of gonadotropin (LH, Luteinising hormone) from anterior pituitary (Zohar and Mylonas, 2001). The commonly used methods to overcome this reproductive dysfunction in fish are environmental manipulation (Zohar, 1989; Yaron, 1995) and administration of exogenous hormone and a potent dopamine receptor antagonist (Zohar et al., 2010). Use of pituitary gland extract (PGE), as an exogenous hormone for induced breeding of fish is a common practice. Due to uncertainty in rates of spawning success and unpredictable activity while using PGE, the use of human chorionic gonadotropin (HCG) is encouraged, because of the latter's higher chemical purity and better efficacy (Zohar and Mylonas, 2001). Use of HCG in spawning induction of thin-lipped grey mullet Liza ramada was reported by Mousa $(1999 ; 2010)$ and Mousa and Mousa (2006). Combination of PGE and HCG was also used for induced spawning of Liza macrolepis (James et al.,1983) and Mugil cephalus (Shehadeh and Ellis, 1970). Moreover, a combination of HCG and ovaprim was used by Abraham et al. (1999) for induced breeding of $M$. cephalus. Administration of GnRHa and dopamine D2 receptor antagonist (DA) induces spawning in M. cephalus (Aizen et al., 2005). Salinity is known to directly affect fertilisation, survival and development of fish eggs (Holliday, 1969; Alderdice, 1998). Catadromous nature of $L$. parsia indicates that salinity is an important factor which influences the final maturation and spawning (Talwar and Jhingran, 2001). It is a migratory species that spawns in seawater during December to February months (Talwar and Jhingran, 2001). With this background, the present experiment was conducted to standardise the 
salinity acclimatisation process for brackishwater reared broodstock of L. parsia and to optimise the doses of different hormones for oocyte maturation and ovulation.

\section{Materials and methods}

\section{Broodstock development}

Before the start of spawning season (December to February), 250 numbers of 2 year old adult L. parsia (body weight range: 50 to $110 \mathrm{~g}$ ) were stocked in a brackishwater tide-fed pond $\left(1200 \mathrm{~m}^{2}\right)$ of Kakdwip Research Centre of ICAR-Central Institute of Brackishwater Aquaculture, West Bengal, India. During rearing, it was fed twice daily with a pellet diet containing $32 \%$ crude protein and $8 \%$ lipid at $3 \%$ of the fish biomass. Broodstock was reared for six months from June to November. Physicochemical parameters of the pond water salinity, temperature, dissolved oxygen and ammonia recorded during the study period were: $7 \pm 1.5 \mathrm{ppt}, 19 \pm 2.5^{\circ} \mathrm{C}, 4.9 \pm 1.5 \mathrm{ppm}$ and $0.05 \pm 0.02 \mathrm{ppm}$, respectively. During breeding season, mature females having oocyte diameter in the range of 480 to $540 \mu \mathrm{m}$ and males with oozing milt were selected for the experiment.

\section{Salinity acclimatisation experiment}

A total of 24 females (average body weight: $78 \pm 12 \mathrm{~g}$ ) and 48 males (average body weight: $34.35 \pm 8 \mathrm{~g}$ ) were randomly distributed in four experimental groups. In each experimental group, six females and twelve males (Male: Female $=2: 1)$ were stocked in FRP tanks (50 1) filled with brackishwater (salinity: $7 \pm 1.5 \mathrm{ppt}$ ). Thereafter, salinity was gradually increased from pond brackishwater salinity $(7 \pm 1.5 \mathrm{ppt})$ to spawning salinity (30 ppt), at three different rates, namely $7.5 \mathrm{ppt}$ in $6 \mathrm{~h}, 3.75 \mathrm{ppt}$ in $6 \mathrm{~h}, 2.5 \mathrm{ppt}$ in $6 \mathrm{~h}$ which took 24,48 and $72 \mathrm{~h}$, respectively. The control group was maintained in brackishwater without altering the water salinity. Before and after salinity acclimatisation, oocytes were collected by in vivo biopsy of ovary using a polyethylene cannula (2 $\mathrm{mm}$ dia) (Shehadeh et al., 1973) and diameter of 30 oocytes were measured immediately under a trinocular microscope (Radical RXLr-5, India) supported with the software ProgRes Capture 2.7. Milt samples, before and after salinity acclimation, were collected and tested for vitality by Eosin-Nigrosin staining (Douglas and Kenneth, 2013). Sperm mortality was calculated as: Total number of dead sperm/Total number of sperm counted x 100 .

\section{Hormone administration experiment}

The second experiment was conducted to assess the effect of administration of different hormones on oocyte growth, ovulation and spawning. From the first experiment, we found that the reduction in oocytes diameter was minimal when salinity acclimatisation from $7 \mathrm{ppt}$ to $30 \mathrm{ppt}$ was accomplished in $24 \mathrm{~h}$. Therefore, broodstock of males and females (average body weight: females $80 \pm 8.0 \mathrm{~g}$ and males $38.00 \pm 4.5 \mathrm{~g}$ ) were collected from broodstock pond and acclimatised in sex ratio of $2: 1$ (Male:Female) to the desired salinity of $30 \mathrm{ppt}$ in $24 \mathrm{~h}$. Thereafter, 30 female and 60 male fishes in sex ratio of 2:1 (Male:Female) were randomly distributed in five FRP tanks (500 1) fitted with recirculatory aquaculture system (RAS) and maintained under natural photoperiod. Different experimental groups were subjected to administration of hormones viz., (a) control (without hormone administration); (b) carp pituitary gland extract (PGE), (c) human chorionic gonadotropin (HCG), (d) combination of PGE $+\mathrm{HCG}$ and (e) luteinising hormone releasing hormone analogue (LHRHa) with dopamine antagonist (DA) metoclopramide.

PGE was prepared by homogenising carp pituitary in $0.9 \%$ physiological saline (Brzuska, 2004). HCG (5000 IU, IBSA Institut Biochimique SA, Switzerland) and LHRHa (Sigma) were dissolved separately in $0.9 \%$ physiological saline. Metoclopramide was prepared by dissolving in distilled water. PGE, HCG and LHRHa were injected intramuscularly at the rate of 0.01 and $0.02 \mathrm{mg} \mathrm{g}^{-1}$, 20 and $40 \mathrm{IUg}^{-1}, 10$ and $20 \mu \mathrm{g} \mathrm{kg}^{-1}$ as primary and secondary doses, respectively. DA, metoclopramide was injected at the dose of $15 \mathrm{mg} \mathrm{kg}^{-1}$ along with LHRHa. The control group received 0.1 and $0.2 \mathrm{ml}$ of $0.9 \%$ physiological saline as primary and secondary doses, respectively.

\section{Maturity assessment}

The stages of maturity were examined based on oocyte diameter and the germinal vesicle $(\mathrm{GV})$ position and classified as: Stage I (central GV), Stage II (migrating/ eccentric GV), Stage III (peripheral GV), Stage IV (germinal vesicle breakdown, GVBD) and Stage V (ovulated oocytes), as per Levavi and Yron (1986). To locate the GV position, a sample of 30 eggs from each female was cleaned with cleaning solution (ethanol: formalin: acetic acid $=6: 3: 1 \mathrm{v} / \mathrm{v}$ ) and observed under a compound microscope.

\section{Ovulation and spawning}

Females were tested for ovulation by hand stripping of the abdomen and ovulation rate was calculated as: Ovulation rate $(\%)=($ No. of ovulated females $/$ No. of injected females) x 100 (Richter et al., 1987). After noticing the spawned eggs in tank, spawning rate was calculated as: Spawning rates $(\%)=($ No. of spawned fish/ Total No. of injected fish) x 100. Latency period (h) i.e., the time period from injection to spawning was also calculated.

\section{Statistical analysis}

In the first experiment, mean values of initial and final oocyte diameter were compared by paired t-test and percentage change in oocyte diameter among different 
acclimatisation times were subjected to one-way ANOVA. In the second experiment, mean value of final oocyte diameter, ovulation and spawning were subjected to one way ANOVA. All statistical analyses were performed with SPSS v. 20.0.

\section{Results and discussion}

Environmental factors such as salinity are known to directly affect fertilisation, survival and normal development of fish eggs (Holliday, 1969; Alderdice, 1998). Salinity does not affect oocyte maturation in European seabass Dicentrarchus labrax (Zanuy and Carrillo, 1984); striped mullet M. cephalus (Lee and Weber, 1986; Tamaru et al., 1994) and black bream Acanthopagrus butcheri (Haddy and Pankhurst, 2000). In the present study, we recorded maturation of male and female L. parsia in brackishwater pond system, where salinity ranged from 5 to $8 \mathrm{ppt}$ (mean: $7 \pm 1.5 \mathrm{ppt}$ ). Similar to this, maturation of L. parsia in brackishwater pond having water salinity of 7 ppt was reported earlier by Alam et al. (2008).

Results of the first experiment showed that the acclimatisation of brackishwater reared brood fish to 30 ppt salinity significantly $(\mathrm{p}<0.05)$ reduced oocyte diameter; however the reduction in oocyte diameter was minimal in $24 \mathrm{~h}$ of acclimation (Table 1). This reduction in oocyte diameter might be due to salinity stress and poor feeding. However there is no published literature to support this finding. However, Yashouv (1969) in M. cephalus and Mousa (2010) in L. ramda reported $24 \mathrm{~h}$ as an ideal time period for salinity acclimatisation. Contradictory to this, Alam et al. (2008) acclimatised brackishwater reared L. parsia to 20 ppt salinity in $72 \mathrm{~h}$ and achieved successful spawning through hormonal administration. Acclimatisation of male broodstock from pond rearing salinity $(7 \mathrm{ppt})$ to breeding salinity $(30 \mathrm{ppt})$ in 24,48 and $72 \mathrm{~h}$ significantly increased $(\mathrm{p}<0.05)$ sperm relative mortality by $15 \pm 4.7,28 \pm 2.8$ and $33.25 \pm 2.6 \%$, respectively (Fig. 1a; b). This inverse relationship between acclimatisation time and viability of sperm in L. parsia, might be due to osmotic imbalance of seminal plasma caused by salinity stress. Lee and Weber (1986) reported that sperm of $M$. cephalus loses its motility when reared at $10 \mathrm{ppt}$ or below. However, in the present study, males of L. parsia reared at $7 \mathrm{ppt}$ had viable sperms, which is similar to the finding of $\mathrm{Hu}$ and Liao (1981) in M. cephalus, who reared the brooders at $7 \mathrm{ppt}$.

In the second experiment, salinity acclimatised females with oocyte diameter in range of $480-500 \mu \mathrm{m}$ (mean: $470 \pm 5.30 \mu \mathrm{m}$ ), having central GV (Fig. 2a; b) were selected for hormonal administration. In this study, dose of PGE (Lee et al.,1987; Vazirzadeh and Ezhdehakoshpour, 2014), HCG (Mousa, 2010) and LhRHa (Aizen et al., 2005)

Table 1. Effect of salinity acclimation from 7 to $30 \mathrm{ppt}$ in 24,48 and $72 \mathrm{~h}$ of duration on oocyte development in L. parsia

\begin{tabular}{llll}
\hline Time $(\mathrm{h})$ & Initial oocyte diameter $(\mu \mathrm{m})$ & Final oocyte diameter $(\mu \mathrm{m})$ & \% change in diameter \\
\hline 24 & $513.50 \pm 5.63$ & $504.83 \pm 7.14$ & $1.63^{\mathrm{c}} \pm 0.02$ \\
48 & $547.83 \pm 10.63$ & $530.16 \pm 7.03$ & $3.09^{\mathrm{b}} \pm 0.50$ \\
72 & $521.00 \pm 21.15$ & $482.66 \pm 14.77$ & $6.26^{\mathrm{a}} \pm 0.03$ \\
Control & $519.33 \pm 3.77$ & $518.83 \pm 4.18$ & $0.086^{\mathrm{d}} \pm 0.01$ \\
\hline
\end{tabular}

Mean values in the same row (Initial and final oocyte diameter) does not differ significantly ( $\mathrm{p}>0.005)$.

Mean values of percentage change in oocytes diameter in a column under each salinity acclimation having different superscripts differ significantly $(\mathrm{p}<0.05)$. Data are shown as mean \pm SE.

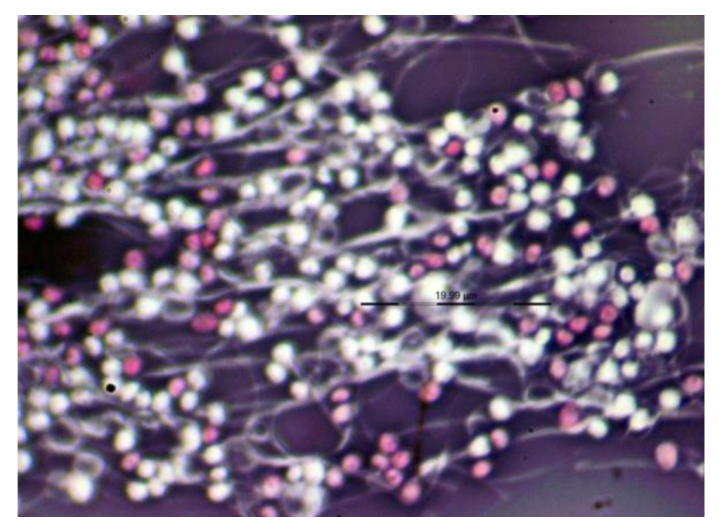

(a)

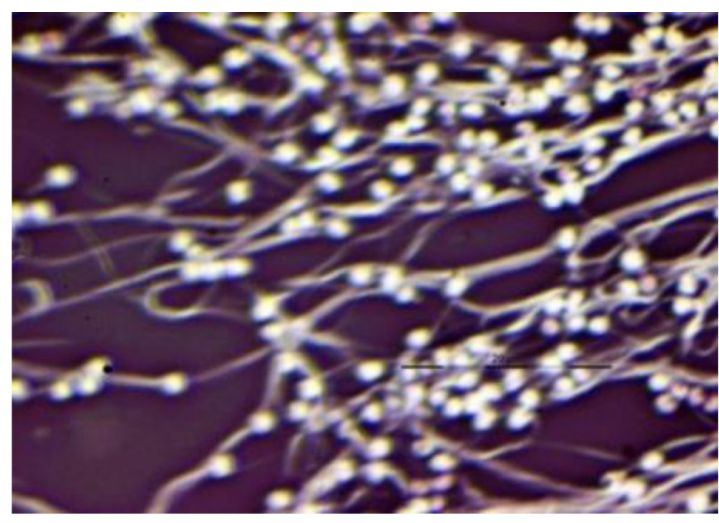

(b)

Fig.1. (a) Effect of salinity acclimation from 7 to $30 \mathrm{ppt}$ on relative mortality of $L$. parsia spermatozoa (x100). (b) Spermatozoa of L. parsia reared in brackishwater pond at salinity of $7 \mathrm{ppt}$. Spermatozoa were stained with Eosin-Nigrosin stain. Live spermatozoa remained unstained and dead spermatozoa stained pink or red 


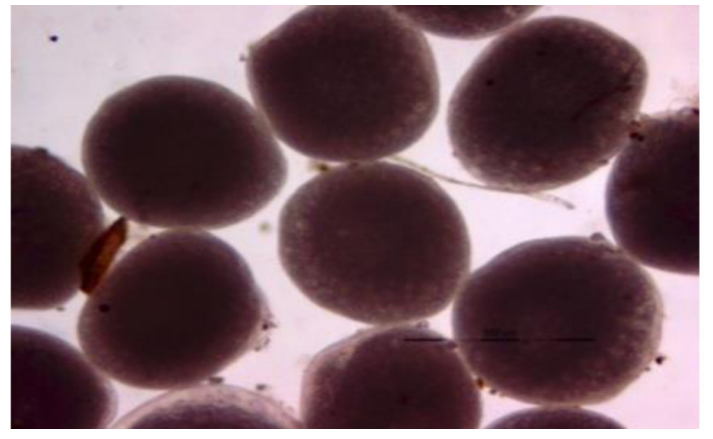

(a)

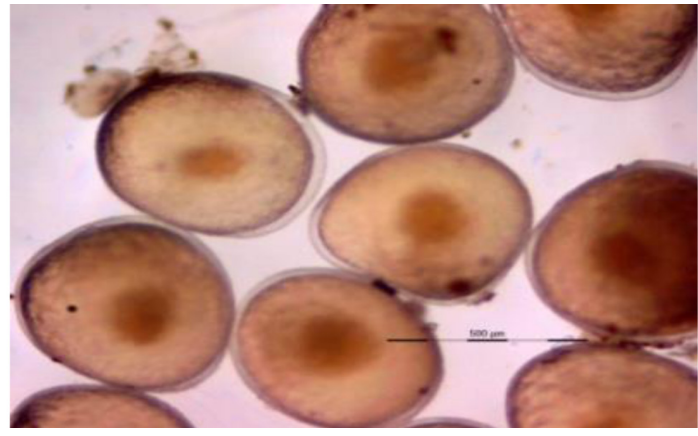

(b)

Fig. 2. Photomicrograph of $L$. parsia oocytes before administration of primary dose of hormone. (a) Oocytes immediately observed after ovarian biopsy (oocyte diameter: $470 \pm 5.30 \mu \mathrm{m}$ ); (b) Oocytes with centrally located germinal vesicle (x40)

were calculated based on commonly used dose for final oocytes maturation (FOM), ovulation and spawning of $M$. cephalus and $L$. ramda. The effects of different exogenous hormone treatments on growth and maturation of L. parsia oocytes is shown in Table 2. In all the experimental groups, $24 \mathrm{~h}$ after primary dose of hormones (PGE, HCG and PGE+HCG) administration, oocyte growth, migration of $\mathrm{GV}$ and fusion of lipid droplets

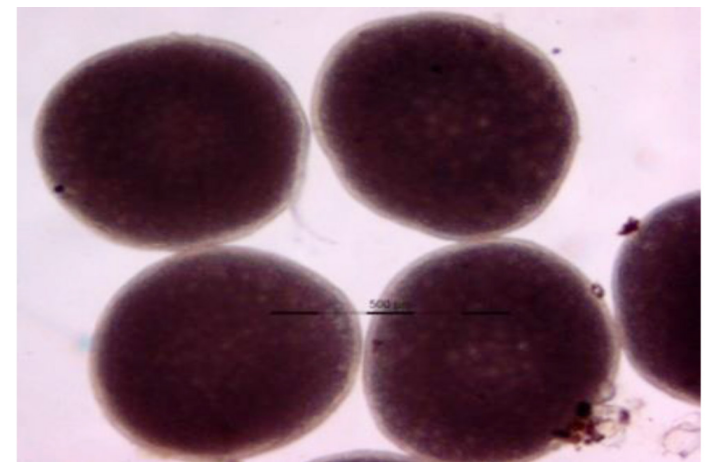

(a) was seen (Fig. 3a; b). Twelve hours after the second dose of PGE, HCG and PGE+HCG administration, oocyte growth, GVBD, homogenisation of yolk protein and thickening of chorion were noticed (Fig. 4a; b). Zaki et al. (1998) have also observed lipid droplet coalescence after administration of double dose of HCG in M. cephalus. Recently Vazirzadeh and Ezhdehakoshpour (2014), reported lipid droplet fusion and oocyte growth

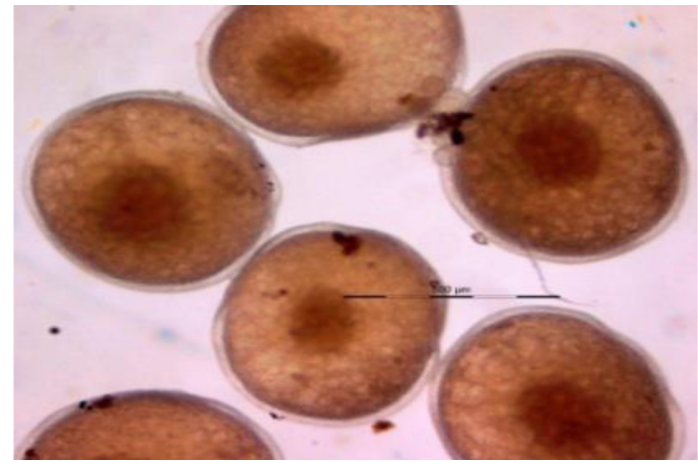

(b)

Fig. 3. Photomicrograph of L. parsia oocytes $24 \mathrm{~h}$ after administration of primary dose of hormone (PGE, $\mathrm{HCG}$ and $\mathrm{PGE}+\mathrm{HCG}$ ). (a) Oocytes immediately observed after ovarian biopsy; (b) Oocytes with migrating or eccentric germinal vesicle and fusion of lipid droplets (x40)

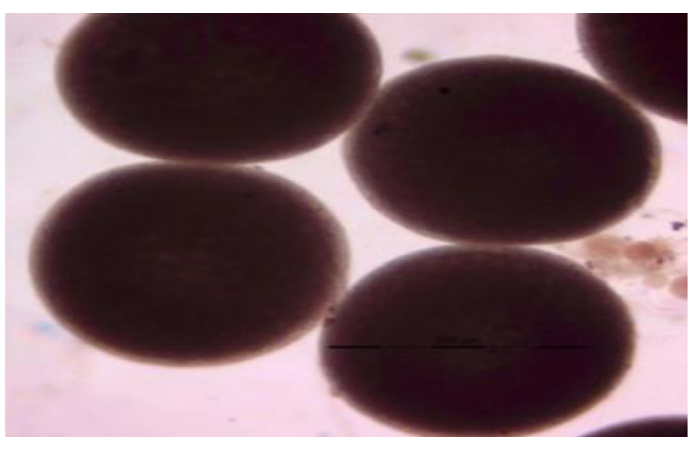

(a)

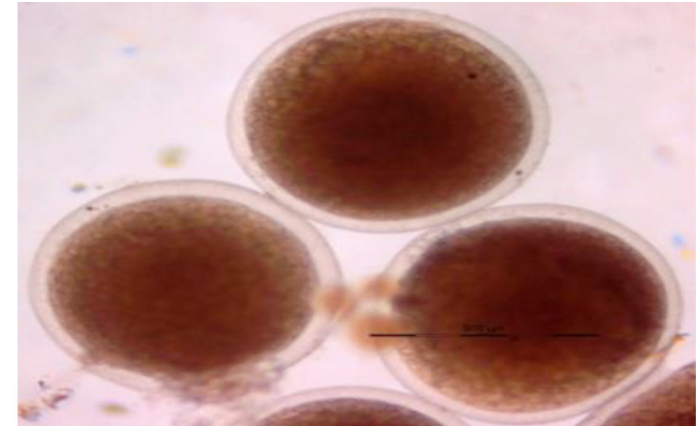

(b)

Fig. 4. Photomicrograph of $L$. parsia oocytes $12 \mathrm{~h}$ after administration of secondary dose of hormone (PGE, HCG and PGE+HCG) (a) Oocytes immediately observed after ovarian biopsy; (b) Oocyte with germinal vesicle break down and yolk homogenisation (x40). 
Table 2. Effect of different hormonal (pituitary gland extract, PGE; human chorionic gonadotropin, HCG; PGE+HCG and luteinizing hormone-releasing hormone analogue, LHRHa + dopamine antagonist (DA) treatments on growth, germinal vesicle position and lipid droplet coalescence in oocytes of $L$. parsia

\begin{tabular}{|c|c|c|c|c|c|c|}
\hline Treatments & $\begin{array}{l}\text { Initial oocyte diameter } \\
\text { in } \mu \mathrm{m} \text { (Beforeprimary } \\
\text { dose/after salinity } \\
\text { acclimation) }\end{array}$ & $\begin{array}{l}\text { Oocyte diameter in } \mu \mathrm{m} \\
\text { ( } 24 \mathrm{~h} \text { after primary dose/ } \\
\text { during secondary dose) }\end{array}$ & $\begin{array}{l}\text { Oocyte diameter } \\
\text { in } \mu \mathrm{m}(24 \mathrm{~h} \text { after } \\
\text { secondary dose })\end{array}$ & $\begin{array}{l}\text { Germinal vesicle } \\
\text { position after } 48 \mathrm{~h} \\
\text { of primary dose }\end{array}$ & $\begin{array}{l}\text { Lipid droplet } \\
\text { coalescence }\end{array}$ & $\begin{array}{l}\% \text { Mortality } \\
\text { of females }\end{array}$ \\
\hline Control & $458.15 \pm 11.20$ & $521.17^{\mathrm{c}} \pm 9.20$ & $520.00^{c} \pm 7.35$ & Central & Not & Nil \\
\hline PGE & $486.13 \pm 15.28$ & $558.63^{\mathrm{a}} \pm 12.72$ & $604.38^{\mathrm{a}} \pm 16.48$ & Eccentric and GVBD & Observed & $27 \pm 2.00$ \\
\hline HCG & $463.88 \pm 10.27$ & $576.63^{\mathrm{a}} \pm 11.66$ & $586.25^{\mathrm{a}} \pm 14.27$ & Eccentric and GVBD & Observed & $38 \pm 5.00$ \\
\hline $\mathrm{PGE}+\mathrm{HCG}$ & $457.13 \pm 12.43$ & $564.88^{\mathrm{a}} \pm 11.74$ & $603.63^{\mathrm{a}} \pm 7.88$ & Eccentric and GVBD & Observed & $35 \pm 3.00$ \\
\hline LHRHa+DA & $535.00 \pm 3.78$ & $547.50^{\mathrm{b}} \pm 11.49$ & $551.75^{\mathrm{b}} \pm 3.47$ & Central & Not seen & $80 \pm 5.00$ \\
\hline
\end{tabular}

Mean values in a column under hormonal treatments having different superscripts differ significantly $(\mathrm{p}<0.05)$. Data are shown as mean \pm

with primary and secondary doses of PGE and LHRHa, respectively in $M$. cephalus. Percentage increase in oocyte diameter, $24 \mathrm{~h}$ after second dose of hormonal administration was significantly $(\mathrm{p}<0.05)$ higher in PGE

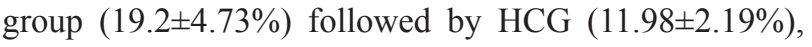
PGE + HCG $(8.74 \pm 2.97 \%)$ and LHRHa+DA groups (3.14 $\pm 0.52 \%)$ (Fig. 5). Compared to other groups, PGE group showed significantly $(\mathrm{p}<0.05)$ higher percentage of ovulation (75\%), which does not vary significantly $(p>0.05)$ from HCG and PGE+HCG groups (Fig. 6a). Compared to other two groups, significantly higher spawning percentage was noticed in PGE and PGE+HCG groups (Fig. 6b). In the present experiment, ovulation and spawning were noticed at $18 \pm 2 \mathrm{~h}$ and $24 \pm 3 \mathrm{~h}$ after second dose of PGE and $\mathrm{HCG}$, respectively. Ovulated oocytes were in size range of $580-615 \mu \mathrm{m}$, which were characterised by single yolk sac (Fig. 7a). Spawned oocytes (diameter range: 680$715 \mu \mathrm{m}$; mean: $710 \pm 1.0 \mu \mathrm{m})$ were characterised by $6-7$ oil globules (Fig. 7b). We did not observe spawning after second dose of LHRHa+DA, however ovulation (Fig. 6a) and atretic oocytes were noticed (Fig. 7c).

Results of the present study demonstrated that primary dose of PGE significantly improved oocyte diameter and maturation in salinity acclimatised L. parsia. This might be due to the presence of many other hormones, such as growth hormone (GH) and thyroid stimulating hormone (TSH), which also have implication in fish maturation (Rocha et al., 2007; Moussavi et al., 2009) in cooperation with gonadotropin. Further, lowest mortality of broodfish was noticed in PGE group, which showed that administration on PGE causes comparatively less stress. In case of group administered with LHRHa+DA, significantly poor ovulation and spawning were noticed, which might be due to sub- and supra-optimal doses of exogenous hormones (Sahoo et al., 2007). In this study, the latency period of ovulation and spawning recorded were $18 \pm 2 \mathrm{~h}$ and $24 \pm 3 \mathrm{~h}$, respectively. These differences could

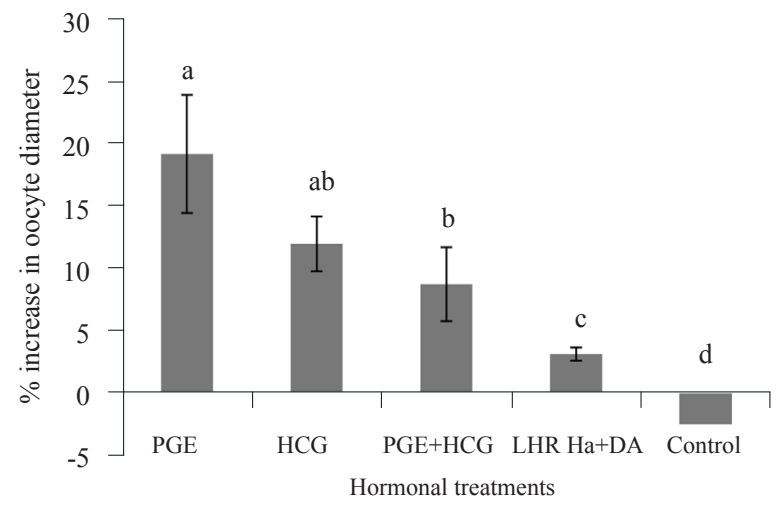

Fig. 5. Effect of different hormonal treatments on percentage increase in oocyte diameter after $48 \mathrm{~h}$ of injection in L. parsia. Different superscripts indicate significant differences between hormonal treatments $(\mathrm{p}<0.05)$.

be attributed to the type and dose of hormonal treatment and environmental conditions. The results of this study demonstrated that primary injection of PGE is required for oocyte growth, and a secondary dose of either PGE or HCG is essential for final oocyte maturation and ovulation in L. parsia. Present findings are in agreement with the studies by Tamaru et al. (1989); Samira et al. (2008) and Yousif et al. (2010), who reported that the prime injection of gonadotropin (PGE or HCG) is essential for successful spawning in M. cephalus.

In conclusion, from this study we were able to infer that acclimatisation to the breeding salinity of $30 \mathrm{ppt}$ in 24 $\mathrm{h}$ is ideal for $L$. parsia. PGE as priming dose $\left(0.01 \mathrm{mg} \mathrm{g}^{-1}\right)$ is essential for oocyte growth and the secondary dose of either PGE $\left(0.02 \mathrm{mg} \mathrm{g}^{-1}\right)$ or HCG $\left(40 \mathrm{IU} \mathrm{g}^{-1}\right)$ is required for final oocyte maturation and ovulation . This understanding will be useful in the development of captive breeding and seed production technology for L. parsia. 


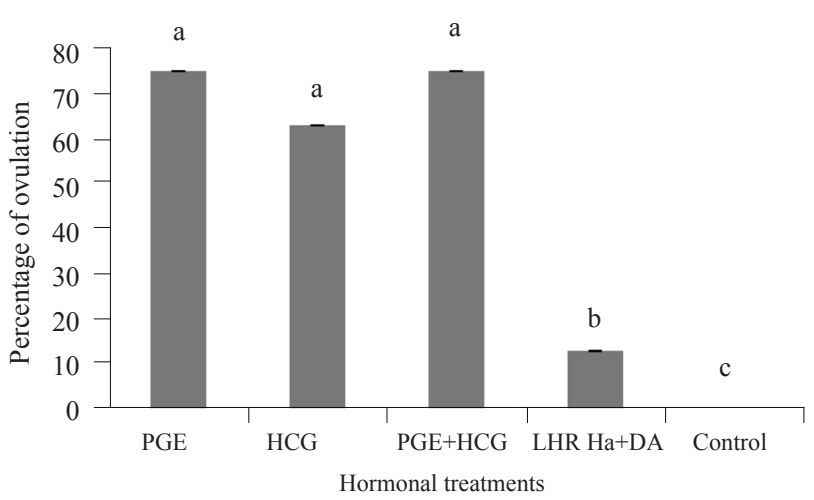

(a)

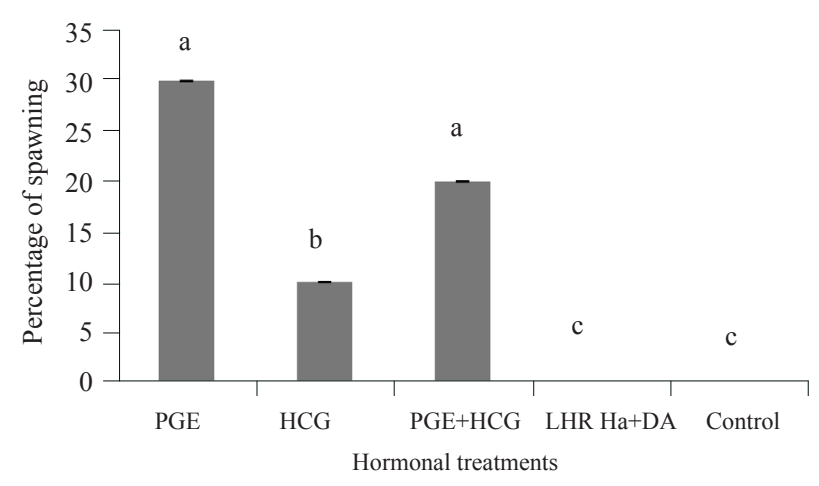

(b)

Fig. 6. Effect of different hormonal treatments on (a) ovulation (\%) and (b) spawning (\%) in L. parsia. Different superscripts indicate significant differences between hormonal treatments $(\mathrm{p}<0.05)$.

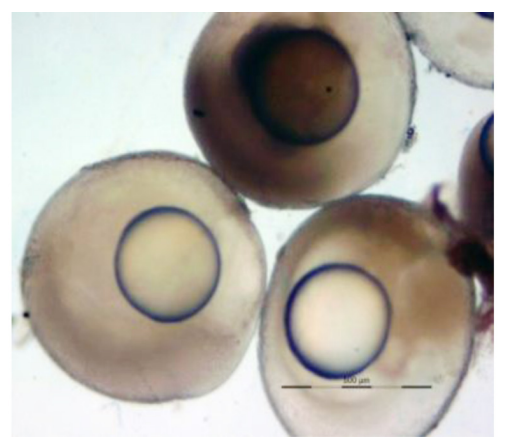

(a)

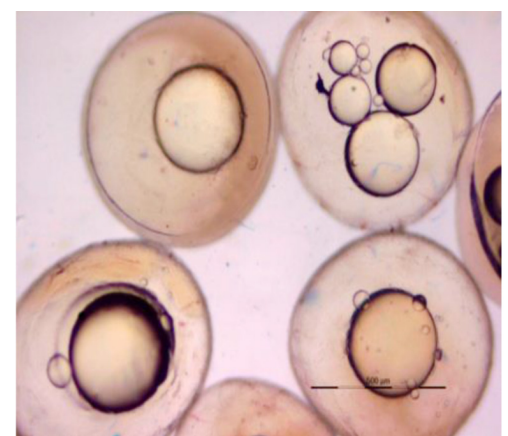

(b)

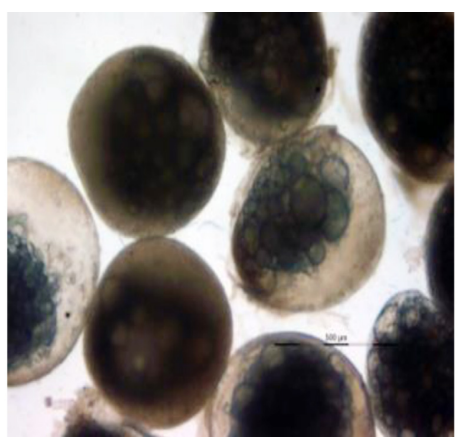

(c)

Fig. 7. Photomicrograph of L. parsia oocytes, (a) Ovulated/hydrated oocytes showing single yolk sac (oocyte diameter: $590 \pm 2.0 \mu \mathrm{m}$ ); (b) Spawned oocytes with 6 to 7 oil globules (oocyte diameter: $710 \pm 1.0 \mu \mathrm{m})$; (c) Atretic oocytes (x40).

\section{Acknowledgements}

Authors are thankful to the Director, ICAR-CIBA, Chennai, India for necessary facilities and Department of Biotechnology (DBT- BT/PR18811/AAQ/3/821/2016) for providing financial support to carry out this research work. The authors also acknowledge Mrs. C. Mazumdar for kind help in the maintenance of animals during the experiment.

\section{References}

Abraham, M., Shiranee, P., Kishore, C. P., Kailasam, M. and Charles, V. K. 1999. Embryonic and larval development of the striped mullet Mugil cephalus (L). Indian J. Fish., 46(2): 123-131.

Aizen, J., Meiri, I., Tzchori, I., Levavi-Sivan, B. and Rosenfeld, H. 2005. Enhancing spawning in the grey mullet (Mugil cephalus) by removal of dopaminergic inhibition. Gen. Comp., Endocrinol., 142(1): 212-221. DOI:10.1016/j. ygcen.2005.01.002.

Alam, M. J., Begum, M., Pal, H. K., Islam, M. A. and Abdullah-Al, Mamun. 2008. Preliminary success on hormone induced captive breeding of goldspot mullet, Liza parsia (Ham.). Bangladesh J. Fish. Res., 12(2): 151-156.
Alderdice, D. F. 1998. Osmotic and ionic regulation in teleost eggs and larvae. In: Hoar, W. S. and Randall, D. J. (Eds.), Fish physiology, Academic Press, London, UK, p. 163-251

Battaglene, S. C. and Selosse, P. M. 1996. Hormone-induced ovulation and spawning of captive and wild broodfish of the catadromous Australian bass, Macquaria novemaculeata (Steindachner) (Percichthyidae). Aquac. Res., 27: 191-204. https://doi.org/10.1111/j.1365-2109.1996.tb00984.x.

Brzuska, E. 2004. Artificial spawning of carp (Cyprinus carpio L.): differences between the effects of reproduction in females of Hungarian, Polish and French origin, treated with carp pituitary homogenate or [D-Tle6, ProNHEt9] GnRH (Lecirelin). Aquac. Res., 35(14): 1318-1327. https://doi. $\operatorname{org} / 10.1111 / \mathrm{j} .1365-2109.2004 .01153 . x$.

Douglas, T. and Carrell Kenneth, I. A. 2013. Spermatogenesis methods and protocols. In: Methods in molecular biology, Springer Science and Business Media,. LLC, New York, USA, p. 13-19.

Haddy, J. A. and Pankhurst, N. W. 2000. The effects of salinity on reproductive development, plasma steroid levels, fertilisation and egg survival in black bream, 
Acanthopagrus butcheri. Aquaculture., 188: 115-131. https://doi.org/10.1016/S0044-8486(00)00326-4.

Holliday, F. G. T. 1969. The effects of salinity on the eggs and larvae of teleosts. In: Hoar, W. S. andRandall, D. J. (Eds.), Fish physiology, Academic Press, London, UK, p. 293-311.

Hu, F. and Liao, I. C. 1981. The effect of salinity on the eggs and larvae of grey mullet, Mugil cephulus. Int. Explor. Mer., 178: 460-466.

James, P. S. B. R., Rengaswamy, V. S., Raju, A., Mohanraj, G. and Gandhi, V. 1983. Induced spawning and larval rearing of the grey mullet, Liza mocrolepis (Smith). Indian J. Fish., 30(2): $185-202$

Lee, C. S. and Weber, G. M. 1986. Effects of salinity and photoperiod on $17 \alpha$-methyltestosterone-Induced spermatogenesis in the grey mullet, Mugil cephalus L. Aquaculture, 56: 53-62.

Lee, C. S., Tamaru, C. S., Miyamoto, G. T. and Kelley, C. D. 1987. Induced spawning of grey mullet (Mugil cephalus) by LHRH-a. Aquaculture, 62: 327-336. DOI: 10.1016/00448486(87)90175-X.

Levavi-Zermonsky, B. and Yaron, Z. 1986. Changes in gonadotropin and ovarian steroids associated with oocytes maturation during spawning induction in the carp. Gen. Comp. Endocrinol., 62: 89-98.

Mousa, M. A. 1999. Hormonal induction of oocyte final maturation and ovulation in thin-lipped grey mullet, Liza ramada (Risso). Bull. Nat. Inst. Oceanogr. Fish., 25: 331-355.

Mousa, M. A. 2010. Induced spawning and embryonic development of Liza ramada reared in freshwater ponds. Anim. Reprod. Sci., 119: 115-122. DOI: 10.1016/j. anireprosci.2009.12.014 .

Mousa, M. A. and Mousa, S. A., 2006. Involvement of corticotropin releasing factor and adrenocorticotropic hormone in the ovarian maturation, seawater acclimation and induced-spawning of Liza ramada. Gen. Comp. Endocrinol., 146: 167-179. DOI:10.1016/j. ygcen.2005.10.002.

Moussavi, M., Nelson, E. R. and Habibi, H. R. 2009. Seasonal regulation of vitellogenin by growth hormone in the goldfish liver. Gen. Comp. Endocrinol., 161: 79-82. DOI:10.1016/j.ygcen.2008.12.009.

Pankhurst, N. W. and Van der Kraak, G. 1997. Fish stress and health in aquaculture. In: Iwama, G. K., Pickering, A. D., Sumpter, J. P. and Schreck C. B. (Eds.), Effects of stress on reproduction and growth of fish. Cambridge University Press, Cambridge, UK, p. 73-93.

Richter, C. J. J., Eding, E. H., Goos, H. J. T., De Leeuw, R., Scott, A. P. and Van Oordt, P. G. W. J. 1987. The effect of pimozide/LHRHa and 17 -hydroxyprogesterone on plasma steroid levels and ovulation in the African catfish, Clarias gariepinus. Aquaculture, 63 (1): 157-68.
Riede, K. 2004. Global register of migratory species - from global to regional scales. Final report, R\&D-Project 808 05 081. Federal Agency for Nature Conservation, Bonn, Germany, $329 \mathrm{pp}$

Rocha, A., Gomez, A., Galay-Borgos, M., Zanuy, S., Sweeney, G. E. and Carrillo, M. 2007. Molecular characterization and seasonal changes in gonadal expression of a thyrotropin receptor in the European seabass. Gen. Comp. Endocrinol., 152: $89-101$

Sahoo, S. K., Giri, S. S., Chandra, S. and Sahu, A. K. 2007. Spawning performance and egg quality of Asian catfish Clarias batrachus (Linn.) at various doses of human chorionic gonadotropin (HCG) injection and latency periods during spawning induction. Aquaculture, 266: 289-292. https://doi.org/10.1016/j.aquaculture.2007.02.006.

Samira, S. A., Alaa, A. and Mona, M. M. 2008. Reproductive biology (histological and ultrastructure) and biochemical studies in ovaries of (Mugil cephalus) from Mediterranean water. J. Arabian Aquac. Soc., 3(1): 1-26.

Shehadeh, Z. H. and Ellis, J. N. 1970. Induced spawning of the striped mullet, Mugil cephalus L. J..Fish. Biol., 2: 355-360. https://doi.org/10.1111/j.1095-8649.1970.tb03293.x.

Shehadeh, Z. H., Kuo, C. M. and Milisen, I. C. 1973. Validation of an in vivo method for monitoring ovarian development in the grey mullet Mugil cephalus. J. Fish. Biol., 5: 489496. https://doi.org/10.1111/j.1095-8649.1973.tb04478.x.

Sumpter, J. P., Pottinger, T. G., Rand-Weaver, M. and Campbell, P. M. 1994. The wide ranging effects of stress in fish. In: Davey, K. G., Peter, , R. E. and Tobe, S. S. (Eds.), Perspectives in comparative endocrinology, National Research Council of Canada, Ottawa. Canada, p. 535-538.

Talwar, P. K. and Jhingran, A. G. 2001. Inland fishes vol. 2. Oxford and IBH Publishing Co. Pvt. Ltd., New Delhi, Inida, $1158 \mathrm{pp}$.

Tamaru, C. S. and Kelley, C. D., Lee, C. S. and Aida K. Hanyu 1989. Effects of chronic LHRH-a $+17 \alpha$-methyltestosterone or LHRH- a+ testosterone therapy on egg growth in the striped mullet (Mugil cephalus). Gen. Comp. Endocrinol., 76: $114-127$

Tamaru, C. S., Lee, C. S., Kelley, C. D., Miyamoto, G. and Moriwake, A. 1994. Oocyte growth in the striped mullet Mugil cephalus L. maturing at different salinities. J. World Aquac. Soc., 25: 109-115. https://doi org/10.1111/j.1749-7345.1994.tb00810.x.

Vazirzadeh, A. and Ezhdehakoshpour, A. 2014. The effects of different hormonal treatments on the oocyte maturation in wild grey mullet (Mugil cephalus) collected from the Iranian coastal waters of the Oman Sea. Iran. J. Ichthyol., 1(1): $17-22$.

Yaron, Z. 1995. Endocrine control of gametogenesis and spawning induction in the carp. Aquaculture, 129: 49-73. 
Yashouv, A. 1969. Preliminary report on induced spawning of Mugil cephalus (L.) reared in captivity in freshwater ponds. Isr. J. Aquac. Bamidgeh, 21: 19-24.

Yousif, O. M., Fatah, A. A., Krishna, K., Minh, D. V. and Hung, B. V. 2010. Induced spawning and larviculture of grey mullet, Mugil cephalus (Linnaeus 1758) in the Emirate of Abu Dhabi. Aquac. Asia, 15(1): 1-3.

Zaki, M. I., Mousa, M., Kamel, S. and Banhawy, E. I. 1998. Effects of exogenous hormone injection on growth and maturation of Mugil cephalus oocytes in captivity. In: Tanacredi, J. T. and Loret, J. (Eds.), Ocean pulse. Springer, Boston, Massachusetts, USA, p 149-161.
Zanuy, S. and Carrillo, M. 1984. Delayed spawning of sea bass after rearing at low salinity. In: Barnabe, G. and Billard, R. (Eds.), The aquaculture of seabass and sparids, INRA, Paris, France, p. 73-80.

Zohar, Y. 1989. Endocrinology and fish farming: Aspects in reproduction, growth and smoltification. Fish. Physiol. Biochem., 7: 395-405.

Zohar, Y. and Mylonas, C. C. 2001. Endocrine manipulations of spawning in cultured fish: From hormones to genes. Aquaculture, 197(1): 99-136.

Zohar, Y., Jose Antonio, Munoz-Cueto, Abigail Elizur and Olivier Kah 2010. Neuroendocrinology of reproduction in teleost fish. Gen. Comp. Endocrinol., 165: 438-455. DOI:10.1016/j. ygcen.2009.04.017. 